\title{
PENGARUH MOTIVASI, KOMPENSASI DAN DISIPLIN KERJA TERHADAP PRODUKTIVITAS KERJA KARYAWAN
}

\author{
Made Dani Suryadewi ${ }^{1}$ \\ Desak Ketut Sintaasih ${ }^{2}$ \\ I Gusti Ayu Ketut Giantari ${ }^{3}$ \\ ${ }^{1,2,3}$ Fakultas Ekonomi dan Bisnis Universitas Udayana, Bali, Indonesia \\ email :danisuryadw@gmail.com
}

\begin{abstract}
ABSTRAK
Tujuan penelitian ini adalah untuk menjelaskan pengaruh motivasi, kompensasi dan disiplin kerja terhadap produktivitas kerja karyawan. Penelitian ini dilakukan pada PT. Lila Buana Wisata yang dimana perusahaan ini bergerak dibidang jasa perjalanan wisata yang terletak di Renon, Denpasar dan Tuban, Badung. Populasi dalam penelitian ini sebanyak 35 orang, dengan menggunakan teknik sampling jenuh maka sampel yang digunakan adalah keseluruhan dari populasi yaitu 35 orang. Teknik analisis data yang digunakan adalah regresi linier berganda. Hasil analisis data, menunjukan bahwa motivasi berpengaruh positif dan signifikan terhadap produktivitas kerja. Kompensasi juga berpengaruh positif dan signifikan terhadap produktivitas kerja. Demikian pula disiplin kerja terbukti berpengaruh positif dan signifikan terhadap produktivitas kerja. Untuk meningkatkan produktivitas kerja karyawan maka perusahaan hendaknya secara terus menerus memotivasi karyawan, memberikan kompensasi yang sesuai dengan beban kerja karyawannya serta menegakkan disiplin karyawan agar produktivitas kerja terus mengalami peningkatan sehingga perusahaan mampu bersaing dan kelangsungan hidup perusahaan terjamin.
\end{abstract}

Kata Kunci : produktivitas kerja, motivasi, kompensasi, disiplin kerja

\begin{abstract}
The purpose of this study was to determine the effect of motivation, compensation and work discipline on employee work productivity. This research was conducted at PT. Lila Buana Wisata where the company is engaged in travel services located in Renon, Denpasar and Tuban, Badung. The population in this study as many as 35 people using saturated sampling techniques, the sample used is the entire population of 35 people. The data analysis technique used is multiple linear regression. Based on the results of data analysis, it was found that motivation has a positive and significant effect on work productivity. Compensation also has a positive and significant effect on work productivity. Similarly, work discipline is proven to have a positive and significant effect on work productivity. To increase employee productivity, the company should continuously motivate employees, provide compensation in accordance with the workload of employees and enforce employee discipline so that work productivity continues to increase so that the company is able to compete and the company's survival is guaranteed.
\end{abstract}

Keywords : work productivity, motivation, compensation, work discipline 


\section{PENDAHULUAN}

Persaingan bisnis yang terjadi saat ini menuntut perusahaan untuk mengembangkan dan mengelola sumber daya yang dimiliki secara optimal agar mampu bertahan dalam persaingan yang ada. Sumber daya manusia adalah salah satu sumber daya yang ada dalam perusahaan yang memegang peranan penting untuk dapat bersaing dengan perusahaan lainnya (Kasmawati, 2018). Samsuni (2017) berpendapat bahwa Sumber daya manusia pada hakikatnya merupakan manusia yang dipekerjakan pada sebuah perusahaan atau organisasi sebagai pemikir, perencana dan penggerak untuk mencapai tujuan yang telah ditetapkan. Oleh sebab itu, penting bagi perusahaan untuk mengelola sumber daya dengan baik agar perusahaan dapat berjalan efektif dan efisien sehingga perusahaan dapat mencapai tujuannya.

Produktivitas menjadi salah satu aspek yang penting pada sebuah perusahaan dalam menentukan kelangsungan usaha dimasa depan (Harliawan et al., 2017). Prabawa \& Supartha (2017) menyatakan bahwa keberhasilan suatu perusahaan atau organisasi bergantung pada produktivitas yang dimiliki, baik secara perseorangan maupun tim dalam perusahaan atau organisasi tersebut. SDM dikatakan produktif, apabila mempunyai produktivitas kerja yang tinggi serta dapat menyelesaikan tugas dan tanggung jawabnya dengan tepat waktu (Ananta \& Adnyani, 2016). Menurut Hanaysha (2016) produktivitas merupakan kemampuan seorang karyawan dalam menyelesaikan tugasnya yang sesuai standar, ketepatan, kelengkapan, biaya dan kecepatan sehingga pemanfaatan sumber daya manusia yang efektif dan efisien. Menurut Mulyadi (2010) pegawai dengan produktivitas yang tinggi menjadi aset penting bagi perusahaan karena akan menunjang pencapaian produktivitas perusahaan tersebut.

Almingo, (2018) menyatakan produktivitas kerja dipengaruhi oleh beberapa faktor yang dibagi menjadi 2 kelompok yaitu faktor intrinsik dan faktor ekstrinsik. Faktor intrinsik yaitu faktor yang muncul dari dalam diri seorang karyawan itu sendiri dan sudah dimiliki sejak awal mulai bekerja. Faktor ekstrinsik yaitu faktor yang menyangkut sesuatu yang berasal dari luar diri seorang karyawan itu sendiri seperti kondisi fisik, lingkungan kerja, sistem manajemen, budaya organisasi pada tempat kerjanya, dan lain sebagainya. Adapun indikator produktivitas kerja yang digunakan dalam penelitian ini yaitu menurut Bintang, (2016). Ia menjelaskan indikator-indikator produktivitas kerja yang digunakan, yaitu : 1) Kemampuan, 2) Meningkatkan hasil yang dicapai, 3) Semangat kerja, 4) Pengembangan diri, 5) Mutu, 6) Efisiensi.

Produktivitas dipengaruhi oleh beberapa faktor yang berkaitan dengan tenaga kerja itu sendiri maupun faktor lainnya (Elqadri et al., 2015). Motivasi menjadi salah satu faktor yang mempengaruhi tingkat produktivitas kerja karyawan menurut Zainal (2017). Motivasi adalah kunci untuk mencapai keinginan atau kebutuhan yang ingin dicapai, dan maka dari itu motivasi pada diri seorang karyawan sangat diperlukan (Muammam et al., 2013). Maduka \& Okafor (2014) menyebutkan, motivasi mempermasalahkan tentang bagaimana cara mengarahkan daya dan potensi karyawan agar mau bekerja lebih baik lagi sehingga tujuan perusahaan bisa tercapai. Berdasarkan penjelasan diatas, dapat disimpulkan bahwa motivasi 
merupakan suatu dorongan dasar yang menjadi alasan seseorang dalam melakukan sesuatu sesuai dengan tujuan yang ditetapkan.

Zainal (2017) menjelaskan tujuan dari motivasi kerja, yaitu meningkatkan moral serta kepuasan kerja pegawai, meningkatkan produktivitas kerja pegawai, meningkatkan kedisiplinan karyawan, meningkatkan kreatifitas, loyalitas dan partisipasi karyawan, meningkatkan tingkat kesejahteraan karyawan, dll. Adapun indikator motivasi kerja digunakan dalam penelitian ini mengacu pada Lusri \& Siagian, (2017), yaitu 1) arah perilaku, 2) tingkat usaha, 3) tingkat kegigihan. Indikator arah perilaku ini diukur melalui perilaku karyawan dalam bekerja seperti dapat menyelesaikan pekerjaannya dengan tepat waktu serta taat pada peraturan yang berlaku. Indikator tingkat usaha ini diukur melalui inisiatif karyawan untuk memecahkan masalah yang ada dalam pekerjaannya. Indikator tingkat kegigihan ini diukur melalui kegigihan karyawan yang dapat bekerja dalam keadaan lingkungan yang kurang mendukung serta dapat bertahan meskipun adanya tantangan dalam pekerjaannya.

Selain motivasi, penelitian yang dilakukan oleh Yamoah (2013) mengatakan bahwa faktor lain yang dapat meningkatkan produktivitas kerja pegawai yaitu kompensasi. Aprilliansyah et al. (2018) mengemukakan bahwa kompensasi merupakan sesuatu yang diterima oleh karyawan sebagai pengganti kontribusi jasa yang mereka lakukan terhadap perusahaan. Kompensasi adalah faktor yang penting untuk menjadi penyemangat dan mempertahankan karyawan yang sudah lama bekerja dalam perusahaan untuk meningkatkan kinerjanya sehingga mempengaruhi produktivitas kerja karyawan (Kusuma et al., 2015). Menurut Ghazanfar (2011), kompensasi merupakan salah satu faktor utama bagi sebuah organisasi yang dipertimbangkan sumber daya manusianya dan hal tersebut cara yang digunakan oleh sebuah organisasi dalam memotivasi karyawannya sehingga produktivitasnya meningkat.

(Kusuma et al., 2015) mengemukakan bahwa terdapat beberapa tujuan dari kompensasi yang perlu diperhatikan, yaitu : 1) Menghargai prestasi kerja, 2) Jaminan keadilan, 3) Mempertahankan karyawan, dan 4) Memperoleh karyawan yang bermutu. Menghargai prestasi kerja, dengan pemberian kompensasi yang memadai adalah suatu penghargaan organisasi terhadap prestasi kerja para karyawan. Jaminan keadilan, dengan adanya sistem kompensasi yang baik akan terjamin terjadinya keadilan di antara karyawan dan organisasi. Mempertahankan karyawan, dengan sistem kompensasi yang baik, para karyawan akan lebih survival bekerja pada organisasi itu. Memperoleh karyawan yang bermutu, dengan kompensasi yang baik akan berpeluang untuk memilih karyawan yang terbaik.

Indikator Kompensasi yang digunakan dalam penelitian ini mengacu pada penelitian yang dilakukan oleh Agustina, (2016), yaitu : 1) Gaji, 2) Insentif, 3) Tunjangan, dan 4) Fasilitas. Gaji, yaitu bentuk pembayaran berupa uang atau sebuah hak yang diberikan oleh perusahaan sesuai dengan beban kerja karyawan. Insentif, merupakan tambahan diluar gaji dan upah yang diberikan oleh perusahaan kepada karyawan bila perusahaan memperoleh hasil yang melampaui target. Tunjangan yaitu kompensasi tambahan yang diberikan berdasarkan kebijakan perusahaan terhadap semua karyawan seperti tunjangan kesehatan dan tunjangan 
hari raya. Fasilitas yaitu sarana yang disiapkan oleh perusahaan kepada karyawan sebagai penunjang kelancaran dalam bekerja.

Salah satu faktor yang berpengaruh dalam meningkatkan produktivitas karyawan lainnya yaitu, disiplin kerja menurut Wardoyo (2015). Menurut Rivai (2011), disiplin kerja merupakan alat yang dipergunakan oleh para manajer untuk berkomunikasi dengan para karyawannya agar mereka bersedia mengubah perilaku dan juga meningkatkan kesadaran karyawan dalam memenuhi segala peraturan yang ada di perusahaannya. Seorang karyawan dikatakan memiliki disiplin kerja yang baik adalah jika karyawan tersebut bertanggung jawab terhadap tugas yang diberikan. Permatasari et al. (2015) mengatakan bahwa disiplin kerja dalah kunci keberhasilan suatu perusahaan dalam mencapai tujuan organisasinya karena semakin baik kedisiplinan karyawan tersebut semakin tinggi prestasi kerjanya maka produktivitasnya akan meningkat.

Hafid (2018), mengemukakan bahwa disiplin kerja mempengaruhi kinerja pegawai, jika disiplin kerja diterapkan pada pegawai maka kecenderungan kinerja pegawai akan meningkat sehingga mempengaruhi kenaikan produktivitas kerja pegawai begitu juga sebaliknya. Menurut (Sibarani, 2013) disiplin kerja dirasa penting, karena jika karyawan tidak disiplin dapat mengganggu produktivitas kerja pegawai dan stabilitas organisasi. Wardoyo (2015) menyatakan bahwa bentuk disiplin yang baik tercermin pada suasana sebagai berikut, yaitu : 1) Tingginya rasa kepedulian karyawan terhadap pencapaian tujuan perusahaan, 2) Tingginya semangat dan gairah kerja inisiatif para karyawan dalam melakukan pekerjaan, 3) Besarnya rasa tanggung jawab para karyawan untuk mejalankan tugas dengan sebaik-baiknya, 4) Berkembangnya rasa memiliki dan solidaritas yang tinggi di kalangan karyawan, 5) Meningkatnya efisiensi dan produktivitas kerja para karyawan.

Indikator yang digunakan dalam penelitian ini mengacu pada penelitian yang dilakukan oleh Suwondo \& Sutanto (2015), yaitu : 1) Ketepatan waktu kerja, 2) Kerapian berpakaian, 3) Kepatuhan pada aturan perusahaan, dan 4) Tanggung jawab. Ketepatan waktu kerja, ketertiban yang dimiliki oleh karyawan dalam hal waktu kedatangan maupun kepulangan saat bekerja, dll yang menandakan bahwa pegawai tersebut memiliki disiplin kerja yang tinggi. Kerapian berpakaian, pegawai yang berpakaian rapi dengan seragam yang sesuai dengan ketentuan yang telah ditetapkan oleh perusahaan. Kepatuhan pada aturan perusahaan, pegawai yang mematuhi aturan perusahaan yang telah ditetapkan memiliki disiplin yang tinggi dalam bekerja sehingga mampu meningkatkan produktivitas karyawan itu sendiri. Tanggung jawab, pegawai yang bertanggung jawab pada setiap pekerjaannya menandakan pegawai tersebut memiliki disiplin kerja yang tinggi dan juga bertanggung jawab atas kesalahan yang dibuatnya.

Penelitian ini menggunakan 2 teori, yaitu Social Exchange Theory dan Expectancy Theory of Motivation. Teori Pertukaran Sosial (Social Exchange Theory) adalah salah satu teori yang mendasari penelitian ini. Salah satu tokoh yang mengembangkan teori pertukaran sosial ini adalah George Caspar Homans pada tahun 1961. Teori pertukaran sosial menggambarkan berbagai transaksi yang terjadi diseluruh kehidupan sosial seseorang yang ditandai dengan hubungan emosional yang kuat. Seseorang akan mengembangkan tingkat saling mendukung yang kuat 
dengan organisasi atau pimpinan mereka, dan dapat menyebabkan perilaku kerja yang efektif, seperti kinerja yang lebih baik, produktivitas kerja yang meningkat dan memberikan lebih banyak bantuan untuk rekan kerja.

Teori lainnya yang digunakan dalam penelitian ini yaitu Expectancy Theory of Motivation yang merupakan teori dari Vroom pada tahun 1964. Teori ini menyatakan bahwa kekuatan yang memotivasi seseorang untuk bekerja giat dalam mengerjakan pekerjaannya tergantung dari hubungan timbal balik antara apa yang diinginkan dan dibutuhkan dari hasil pekerjaan itu. Asumsi Vroom dalam teori harapan ini yaitu setiap individu percaya bila ia berprilaku dengan cara tertentu, ia akan memperoleh hal tertentu. Menurut Vroom, tinggi rendahnya motivasi seseorang ditentukan oleh tiga komponen, yaitu: 1) Ekspektasi(harapan)

keberhasilan kepada suatu tugas. 2) Instrumentalis, yaitu penilaian tentang apa yang akan terjadi jika berhasil dalam melakukan suatu tugas (keberhasilan tugas untuk mendapatkan outcome tertentu). 3) Valensi, yaitu respons terhadap outcome seperti perasaan positif, netral, atau negatif. Motivasi tinggi jika usaha menghasilkan sesuatu yang melebihi harapan, sedangkan motivasi rendah jika usahanya menghasilkan kurang dari yang diharapkan.

Penelitian ini dilakukan di PT. Lila Buana Wisata yang merupakan sebuah perusahaan yang mengkhususkan diri pada pada penyediaan jasa paket wisata kedalam maupun luar negeri. PT. Lila Buana Wisata memiliki 2 cabang yang bertempat di daerah renon dan tuban. PT. Lila Buana Wisata sendiri telah berdiri sejak Juli 1997, yang dimana pada awal berdirinya perusahaan ini adalah hanya sebagai konsultan perjalanan di hotel Orange Kuta. Sebagai salah satu perusahaan yang bergerak dibidang pelayanan jasa perjalanan wisata dengan tingkat kompetisi yang tinggi diantara banyaknya perusahaan sejenis yang bergerak dalam bidang yang sama, maka PT. Lila Buana Wisata perlu meningkatkan produktivitas karyawannya.

Menurut observasi, terdapat permasalahan yang berkaitan dengan produktivitas kerja pada PT. Lila Buana Wisata yang dapat dilihat dari hasil penjualannya yang ditunjukan pada Tabel 1 .

Tabel 1.

Hasil Penjualan Paket Wisata PT. Lila Buana Wisata pada Tahun 2015-2018

\begin{tabular}{ccccc}
\hline Tahun & Jumlah Wisatawan & Hasil Penjualan & & $\begin{array}{c}\text { Persentase } \\
\text { Pencapaian } \\
\text { Target } \\
\mathbf{( \% )}\end{array}$ \\
\hline 2015 & (orang) & $(\mathbf{R p )}$ & $\begin{array}{c}\text { Target Penjualan } \\
(\mathbf{R p})\end{array}$ & $\begin{array}{c}\text { ( }) \\
2016\end{array}$ \\
1039 & 16.509 .710 .000 & 20.000 .000 .000 & 82,55 \\
2017 & 1117 & 18.128 .910 .000 & 20.000 .000 .000 & 90,64 \\
2018 & 1004 & 15.843 .120 .000 & 20.000 .000 .000 & 79,22 \\
\hline
\end{tabular}

Sumber: PT. Lila Buana Wisata, 2019

Tabel 1. menunjukkan hasil penjualan paket wisata pada PT. Lila Buana Wisata dalam kurun waktu empat tahun terakhir. Tabel 1. menunjukkan bahwa penjualan paket wisata PT. Lila Buana Wisata mengalami fluktuasi dan persentase pencapaian target tidak mencapai $100 \%$ setiap tahunnya atau dapat dikatakan bahwa target perusahaan yang tidak pernah tercapai selama empat tahun terakhir 
ini yang menjelaskan adanya ketidakstabilan produktivitas kerja pada PT. Lila Buana Wisata seperti yang dikatakan oleh Fauzi \& Widjana (2018) yaitu masalah produktivitas kerja karyawan akan berpengaruh pada pencapaian target perusahaan.

Hasil dari wawancara yang dilakukan terhadap sales \& marketing manager dari PT. Lila Buana Wisata pada tanggal 8 April 2019, bahwa hampir setiap bulannya dalam kurun waktu satu tahun terakhir ini PT. Lila Buana Wisata menerima banyak keluhan dari pelanggan yang mengatakan jika pelayanan dari karyawan PT. Lila Buana Wisata sangat lambat dan banyak kesalahan yang dilakukan oleh karyawan seperti salah penulisan nama dalam tiket pesawat dan lainlain, sehingga proses closing untuk pelanggan tersebut belum optimal. Hal tersebut membuat para pelanggan enggan untuk menggunakan jasa dari PT. Lila Buana Wisata kembali dan menyebabkan terjadinya fluktuasi pada penjualan seperti yang ditunjukan pada Tabel 1. Keluhan lainnya yaitu, pelanggan merasa tidak puas terhadap kinerja dari tour guide yang dianggap tidak informatif dalam tur. Fenomena diatas mengindikasikan bahwa terdapat masalah pada produktivitas karyawan di PT. Lila Buana Wisata.

Berkaitan dengan banyaknya keluhan dari pelanggan yang diterima karyawan PT. Lila Buana Wisata, mengindikasikan bahwa kurangnya motivasi karyawan dalam bekerja. Indikasi kurangnya motivasi karyawan PT. Lila Buana Wisata juga dapat dilihat dari karyawan yang tidak menyelesaikan pekerjaannya dengan baik dan tidak tepat waktu. Penelitian yang dilakukan oleh Zameer et al. (2014) mengemukakan bahwa peran motivasi kerja sangat vital untuk meningkatkan kinerja karyawan sehingga produktivitasnya akan meningkat.

Selain itu, berdasarkan obeservasi awal pada tanggal 8 April 2019 terhadap 7 karyawan di PT. Lila Buana Wisata diketahui bahwa terdapat masalah kompensasi pada PT. Lila Buana Wisata. Kompensasi khususnya gaji yang seharusnya diterima tepat waktu oleh para karyawan PT. Lila Buana Wisata, namun malah terbalik yaitu karyawan tidak menerima kompensasi dengan tepat waktu dan tidak bisa memenuhi kebutuhannya. Hal tersebut dapat menyebabkan penurunan produktivitas kerja karyawan.

Terdapat indikasi yang menunjukan kurangnya disiplin kerja karyawan yang diketahui dari wawancara terhadap sales \& marketing PT. Lila Buana Wisata. Terdapat beberapa karyawan PT. Lila Buana Wisata melakukan tindakan-tindakan yang kurang mematuhi aturan seperti karyawan yang terlambat masuk kerja, karyawan ijin keluar pada saat jamnya bekerja dan juga tidak mematuhi aturan untuk seragam yang sudah ditetapkan oleh perusahaan. Hal-hal tersebut mengindikasikan bahwa disiplin kerja karyawan PT. Lila Buana Wisata yang rendah.

Perusahaan harus terus memotivasi para karyawannya, karena hal tersebut dapat mendorong karyawan-karyawannya untuk bekerja lebih baik lagi seperti yang dikatakan oleh Jayarathna (2014) dalam penelitiannya, motivasi berpengaruh terhadap produktivitas kerja para karyawan. Dalam penelitian yang dilakukan oleh Chaudary \& Sharma (2012), mengemukakan bahwa motivasi sangat berpengaruh terhadap produktivitas karyawan dan memperloeh hasil yang positif dan signifikan. Selain itu, Maduka dan Okafor (2014) dalam penelitiannya, memperoleh hasil yang 
sama bahwa motivasi berpengaruh positif dan signifikan terhadap produktivitas kerja.

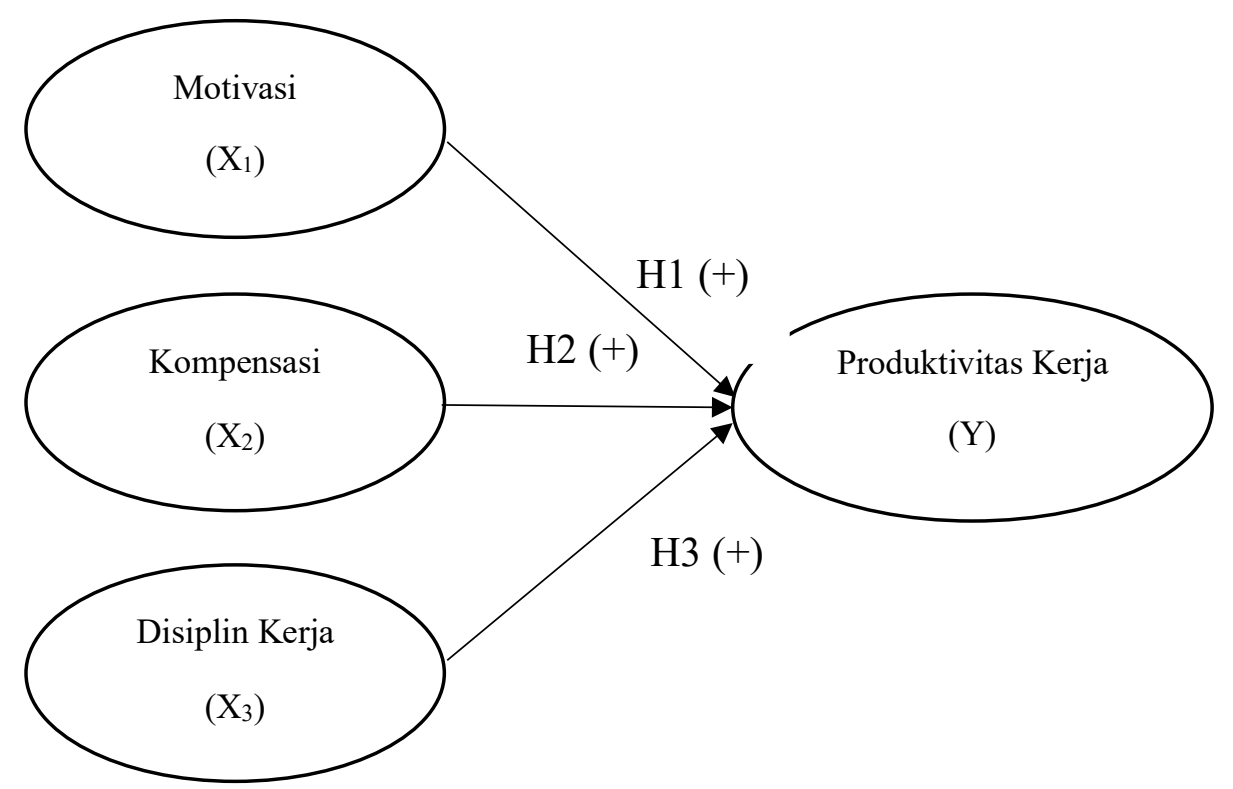

Gambar 1. Model Kerangka Konseptual

Penelitian yang dilakukan oleh Nuraini et al. (2015) menyatakan bahwa, motivasi berpengaruh secara parsial terhadap produktivitas kerja karyawan. Purwanto \& Wulandari (2016) mendapatkan hasil dari penelitiannya yaitu, motivasi berpengaruh secara positif dan signifikan terhadap produktivitas kerja. Penelitian lain yang dilakukan oleh Jayarathna (2014) mendapatkan hasil bahwa motivasi berpengaruh secara positif terhadap prouktivitas kerja. Pengaruh yang positif tersebut menunjukan bahwa semakin baik persepsi responden mengenai dorongan motivasi kerja karyawan telah berhasil meningkatkan produktivitas kerja. Dengan demikian, semakin baik motivasi yang diberikan pada karyawan maka produktivitas kerja karyawan semakin baik juga. Berdasarkan penelitian terdahulu, maka dapat disusun hipotesis sebagai berikut :

$\mathrm{H}_{1}$ : Motivasi berpengaruh positif dan signifikan terhadap produktivitas kerja karyawan

Kompensasi merupakan suatu imbalan yang diberikan atas jasa-jasa yang telah karyawan berikan dalam menyelesaikan suatu pekerjaan yang diberikan oleh perusahaan. Dengan pemberian kompensasi, semata-mata untuk membangun kinerja karyawan dan meningkatkan produktivitas kerja. Penelitian sebelumnya, yang dilakukan oleh Abdussamad (2014), mendapatkan hasil bahwa kompensasi berpengaruh signifikan terhadap produktivitas kerja. Perawati et al. (2018) dalam penelitiannya, menemukan bahwa terdapat pengaruh yang signifikan antara kompensasi dan produktivitas kerja.

Penelitian sebelumnya, yang dilakukan oleh Abdussamad (2014), mendapatkan hasil bahwa kompensasi berpengaruh signifikan terhadap produktivitas kerja. Perawati et al. (2018) dalam penelitiannya, menemukan bahwa terdapat pengaruh yang signifikan antara kompensasi dan produktivitas 
kerja.Peneliti lain yaitu Yuliandari et al. (2014) memperoleh hasil bahwa kompensasi berpengaruh positif dan signifikan terhadap produktivitas kerja karyawan pada UD. Yuri Desa Pangkung Buluh Kecamatan Melaya Kabupaten Jembrana. Peneliti lain, Purwanto \& Wulandari (2016) mengatakan bahwa kompensasi mempunyai pengaruh positif dan signifikan terhadap produktivitas kerja karyawan. Dengan demikian, semakin baik kompensasi yang diberikan pada karyawan maka produktivitas kerja karyawan semakin baik juga. Berdasarkan penelitian terdahulu, maka dapat disusun hipotesis sebagai berikut :

$\mathrm{H}_{2}$ : Kompensasi berpengaruh positif dan signifikan terhadap produktivitas kerja karyawan

Labudo (2013), menyatakan bahwa peningkatan produktivitas dapat dicapai jika karyawan mempunyai disiplin kerja dalam melaksanakan tugas dan kewajibannya. Dalam penelitiannya, mengatakan bahwa disiplin kerja merupakan variabel yang dominan, sehingga paling berpengaruh terhadap produktivitas kerja karyawan. Ruauw, dkk. (2015) dalam penelitiannya, mendapatkan hasil bahwa disiplin kerja pegawai berpengaruh signifikan terhadap produktivitas kerja pegawai.

Ruauw et al. (2015) dalam penelitiannya, mendapatkan hasil bahwa disiplin kerja pegawai berpengaruh signifikan terhadap produktivitas kerja pegawai. Christian \& Farida (2016) mengatakan bahwa disiplin kerja yang baik maka produktivitas kerja karyawan akan baik juga. Dalam penelitiannya, mereka menemukan bahwa pengaruh disiplin kerja terhadap produktivitas kerja karyawan yaitu berpengaruh signifikan. Peneliti lain, Ananta \& Adnyani (2016) dalam penelitiannya, mengatakan bahwa disiplin kerja berpengaruh positif dan signifikan terhadap produktivitas kerja karyawan. (Wardoyo, 2015) dalam penelitiannya menemukan hasil bahwa terdapat pengaruh yang signifikan antara disiplin kerja dengan produktivitas kerja. Berdasarkan penelitian terdahulu, maka dapat disusun hipotesis sebagai berikut :

$\mathrm{H}_{3}$ : Disiplin kerja berpengaruh positif dan signifikan terhadap produktivitas kerja karyawan

\section{METODE PENELITIAN}

Penelitian ini dilakukan pada biro perjalanan wisata yaitu PT. Lila Buana Wisata yang berlokasi di Jalan Raya Puputan No. 16 D, Renon dan Jalan By Pass Ngurah Rai, Tuban. Lokasi ini dipilih untuk membantu memecahkan masalah mengenai produktivitas kerja karyawan, agar lebih meningkatkan produktivitas karyawan PT. Lila Buana Wisata. Obyek penelitian yang akan digunakan untuk penelitian ini adalah motivasi, kompensasi, disiplin kerja dan produktivitas kerja karyawan PT. Lila Buana Wisata.

Populasi dalam penelitian ini adalah keseluruhan karyawan dari PT. Lila Buana Wisata yang berjumlah 35 orang, yang tersebar dalam beberapa divisi. Dalam penelitian ini digunakan teknik sampling jenuh yaitu keseluruhan dari populasi yang ada yang dimana berjumlah 35 orang karyawan. Mengingat jumlah sampel responden sebesar 35 orang sehingga layak untuk diambil keseluruhannya untuk dijadikan responden. 
Penelitian ini dilakukan dengan menggunakan pendekatan kuantitatif yang berbentuk asosiatif untuk meneliti data yang bersifat statistik serta menguji suatu hipotesis dengan kuisioner berbentuk pernyataan sebagai instrumen yang dipakai. Hal ini dikarenakan terdapat hubungan kausal (sebab-akibat) antara variabel bebas $\left(\mathrm{X}_{1} \mathrm{X}_{2} \mathrm{X}_{3}\right)$ yaitu motivasi, kompensasi dan disiplin kerja dengan variabel terikat (Y) yaitu produktivitas kerja. Desain penelitian ini bertujuan untuk mengetahui kebenaran dari suatu masalah yang terjadi dengan dilakukan perhitungan analisis data menggunakan teknik analisis yang sesuai dengan penelitian.

Metode regresi linier berganda yang digunakan dalam penelitian ini untuk mengetahui pengaruh motivasi $\left(\mathrm{X}_{1}\right)$, kompensasi $\left(\mathrm{X}_{2}\right)$, disiplin kerja $\left(\mathrm{X}_{3}\right)$ dan produktivitas kerja (Y). Metode ini diuji menggunakan sistem komputer yaitu program Statistical Package of Social Science (SPSS) 23 for windows. Adapun model regresi linear berganda yang dapat dijabarkan dengan menggunakan persamaan sebagai berikut:

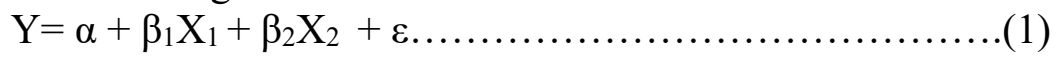

Keterangan:

$$
\begin{array}{ll}
\alpha & =\text { Konstanta } \\
\beta_{1} \beta_{2} & =\text { Koefisien regresi } \\
\mathrm{Y} & =\text { Produktivitas Kerja } \\
\mathrm{X}_{1} & =\text { Motivasi } \\
\mathrm{X}_{2} & =\text { Kompensasi } \\
\mathrm{X}_{3} & =\text { Disiplin Kerja } \\
\varepsilon & =\text { Error }
\end{array}
$$

\section{HASIL DAN PEMBAHASAN}

Adapun gambaran dari karakteristik responden penelitian ini dapat digambarkan pada Tabel 2 .

Data karakteristik responden merupakan data responden yang dikumpulkan untuk mengetahui profil responden penelitian. Responden pada penelitian ini yaitu karyawan dari PT. Lila Buana Wisata. Berdasarkan Tabel 2, PT. Lila Buana Wisata sebagian besar karyawannya yaitu berpendidikan akhir SLTA/sederajat dengan jumlah 20 orang yang dimana memiliki persentase $57,1 \%$, sedangkan persentase terkecil yaitu karyawan dengan pendidikan terakhir diploma yang berjumlah 7 orang dengan persentase 20\%. Karyawan PT. Lila Buana Wisata dengan status perkawinan belum kawin yang paling mendominasi yakni 20 orang atau 57,1\% dari keseluruhan. Karyawan PT. Lila Buana Wisata sebagian besar memiliki masa kerja selama antara $3-5$ tahun dengan persentase $42,9 \%$.

Tabel 2. menunjukan karakteristik responden berdasarkan jenis kelamin, usia, pendidikan terakhir, status perkawinan, dan masa kerja. Berdasarkan Tabel 2, karyawan PT. Lila Buana Wisata dengan jenis kelamin perempuan lebih mendominasi yaitu sebanyak 21 orang dengan persentase $60 \%$ sedangkan karyawan dengan jenis kelamin laki-laki sebanyak 14 orang dengan persentase $40 \%$. Berdasarkan usia, diketahui bahwa karyawan PT. Lila Buana Wisata sebagian besarnya berusia antara 26 - 30 tahun yaitu berjumlah 19 orang dengan persentase 
$54,3 \%$ yang dimana pada umur ini seorang tenaga kerja dapat dikatakan produktif dalam bekerja.

Tabel 2.

Karakteristik Responden

\begin{tabular}{cccc}
\hline Kriteria & Klasifikasi & $\begin{array}{c}\text { Jumlah Responden } \\
\text { (Orang) }\end{array}$ & $\begin{array}{c}\text { Persentase } \\
(\mathbf{\%})\end{array}$ \\
\hline Jenis Kelamin & Laki-laki & 14 & 40 \\
Jumlah & Perempuan & 21 & 60 \\
& & $\mathbf{3 5}$ & $\mathbf{1 0 0}$ \\
Usia & $21-25$ & 7 & 20 \\
& $26-30$ & 19 & 54,3 \\
Jumlah & $>30$ & 9 & 25,7 \\
Pendidikan & & $\mathbf{3 5}$ & $\mathbf{1 0 0}$ \\
Terakhir & SLTA/Sederajat & 20 & 57,1 \\
Jumlah & Diploma & 7 & 20 \\
Status Perkawinan & Sarjana & 8 & 22,9 \\
Jumlah & Kawin & $\mathbf{3 5}$ & $\mathbf{1 0 0}$ \\
& Belum Kawin & 15 & 42,9 \\
Masa Kerja & & 20 & 57,1 \\
& $1-3$ & $\mathbf{3 5}$ & $\mathbf{1 0 0}$ \\
Jumlah & $3-5$ & 11 & 31,4 \\
& $>5$ & 15 & 42,9 \\
\end{tabular}

Sumber: Data diolah, 2019 Tabel 3.

Berikut adalah hasil analisis regresi linier berganda yang ditunjukkan pada

Tabel 3.

Hasil Analisis Regresi Linier Berganda

\begin{tabular}{|c|c|c|c|c|c|c|c|}
\hline \multicolumn{8}{|c|}{ Coefficients $^{\mathrm{a}}$} \\
\hline \multirow{2}{*}{\multicolumn{3}{|c|}{ Model }} & \multicolumn{2}{|c|}{$\begin{array}{l}\text { Unstandardized } \\
\text { Coefficients }\end{array}$} & \multirow{2}{*}{$\begin{array}{c}\text { Standardized } \\
\text { Coefficients } \\
\text { Beta }\end{array}$} & \multirow[t]{2}{*}{$\mathbf{t}$} & \multirow[t]{2}{*}{ Sig. } \\
\hline & & & B & Std. Error & & & \\
\hline \multirow[t]{4}{*}{1} & (Constant) & & 7.684 & 1.405 & & 5.469 & .000 \\
\hline & Motivasi & & .256 & .111 & .269 & 2.316 & .027 \\
\hline & Kompensasi & & .291 & .103 & .365 & 2.835 & .008 \\
\hline & Disiplin Kerja & & .275 & .059 & .438 & 4.625 & .000 \\
\hline & uare & $: 0,806$ & & & & & \\
\hline & sed R Square & $: 0,787$ & & & & & \\
\hline & ing & $: 42,854$ & & & & & \\
\hline Sig & & $: 0,000$ & & & & & \\
\hline
\end{tabular}

Pengujian ini bertujuan untuk menguji signifikasi Motivasi $\left(\mathrm{X}_{1}\right)$, Kompensasi $\left(\mathrm{X}_{2}\right)$, Disiplin kerja $\left(\mathrm{X}_{3}\right)$, terhadap variabel terikatnya yaitu Produktivitas kerja $(\mathrm{Y})$. Berdasarkan Tabel 3 hasil analisis regeresi linier berganda, diperoleh nilai signifikansi $\mathrm{F}$ sebesar 0,000 . Nilai signifikan $0,000<0,05$ mempunyai arti bahwa Motivasi, Kompensasi, dan Disiplin kerja diduga secara signifikan berhubungan dengan Produktivitas kerja. 
Uji t digunakan untuk menguji pengaruh variabel bebas terhadap variabel terikat secara parsial atau untuk menguji hipotesis di dalam penelitian, apakah variabel $\mathrm{X}_{1}, \mathrm{X}_{2}, \mathrm{X}_{3}$, (Motivasi, Kompensasi, Disiplin kerja) benar-benar berpengaruh terhadap variabel Y (Produktivitas kerja) secara terpisah atau parsial.

Berdasarkan Tabel 3. hasil uji t pengaruh Motivasi terhadap Produktivitas kerja diperoleh nilai signifikansi sebesar 0,027 dengan nilai koefisien regresi sebesar 0,256 bernilai positif. Nilai signifikansi $0,027<0,05$ mengindikasikan bahwa $\mathrm{H}_{1}$ diterima. Hasil ini mempunyai arti bahwa Motivasi diduga secara signifikan berhubungan dengan Produktivitas kerja.

Berdasarkan Tabel 3. hasil uji t pengaruh Kompensasi terhadap Produktivitas kerja diperoleh nilai signifikansi sebesar 0,008 dengan nilai koefisien regresi sebesar 0,291 bernilai positif. Nilai signifikansi $0,008<0,05$ mengindikasikan bahwa $\mathrm{H}_{1}$ diterima. Hasil ini mempunyai arti bahwa Kompensasi diduga secara signifikan berhubungan dengan Produktivitas kerja.

Berdasarkan Tabel 3. hasil uji $t$ pengaruh Disiplin kerja terhadap Produktivitas kerja diperoleh nilai signifikansi sebesar 0,000 dengan nilai koefisien regresi sebesar 0,275 bernilai positif. Nilai signifikansi $0,014<0,05$ mengindikasikan bahwa $\mathrm{H}_{1}$ diterima. Hasil ini mempunyai arti bahwa Disiplin kerja diduga secara signifikan berhubungan dengan Produktivitas kerja.

Analisis determinasi merupakan besaran yang menunjukkan besarnya variasi variabel dependen yang dapat dijelaskan oleh variable independennya. Dengan katalain, koefisien determinasi ini digunakan untuk mengukur seberapa jauh variabel-variabel bebas dalam menerangkan variabel terikatnya. Nilai koefisien determinasi ditentukan dengan nilai adjusted $R$ square. Berdasarkan Tabel 3 dapat diamati nilai adjusted $\mathrm{R}^{2}$ sebesar 0,787 berarti $78,7 \%$ perubahan (naik turun) pada Produktivitas kerja yang dipengaruhi oleh Motivasi, Kompensasi, dan Disiplin kerja, sementara sisanya sejumlah $21,3 \%$ dipengaruhi oleh faktor - faktor lain diluar penelitian ini.

Uji normalitas bertujuan untuk menguji apakah dalam residual terdiri dari model regresi yang dibuat berdistribusi normal atau tidak. Regresi yang baik memiliki residual yang normal atau mendekati normal. Dalam penelitian ini metode yang digunakan untuk uji normalitas yaitu metode statistik one sample Kolmogorov-Smirnov. Data tersebut dikatakan normal apabila sig $>\alpha$.

Berdasarkan Gambar 2. dapat dilihat data menyebar disekitar garis diagonal dan mengikuti arah garis diagonal atau grafik histogramnya menunjukkan pada distribusi normal, maka model regresi memenuhi asumsi normalitas.

Uji heterokedastisitas digunakan untuk menguji apakah dalam suatu model regresi ketidaksamaan varians dari residual satu pengamatan ke pengamatan lain. Regresi yang baik tidak mengandung gejala heterokedastisitas. Dalam penelitian ini metode yang digunakan yaitu melalui uji glejser, dimana dengan cara meregresi variabel bebas terhadap absolute residualnya. Dan jika tidak satupun variabel bebas berpengaruh signifikan terhadap variabel terikat maka tidak terjadi heteroskedastisitas. Dalam uji glejser, model regresi tidak mengandung adanya heteroskedastisitas apabila probabilitas signifikansinya di atas $(0,05)$. 
Tabel 4.

Hasil Uji Normalitas

\begin{tabular}{llr}
\hline & One-Sample Kolmogorov-Smirnov Test & Unstandardized Residual \\
\hline $\mathrm{N}$ & & 35 \\
Normal Parameters & & Mean \\
& Std. Deviation & .0000000 \\
Most Extreme Differences & Absolute & .87597854 \\
& Positive & .127 \\
Test Statistic & Negative & .127 \\
Asymp. Sig. (2-tailed) & & -.077 \\
a. Test distribution is Normal. & & .127 \\
b. Calculated from data. & & $.163^{c}$ \\
c. Lilliefors Significance Correction. & \\
\hline Sumber: Data diolah, 2019 &
\end{tabular}

Sumber: Data diolah, 2019

Berdasarkan Tabel 4. diketahui nilai signifikansi dengan menggunakan uji Asymp. Sig. (2-tailed) sebesar 0,163 > 0,05 maka dapat disimpulkan bahwa model regresi yang digunakan dalam penelitian ini terdistribusi secara normal.

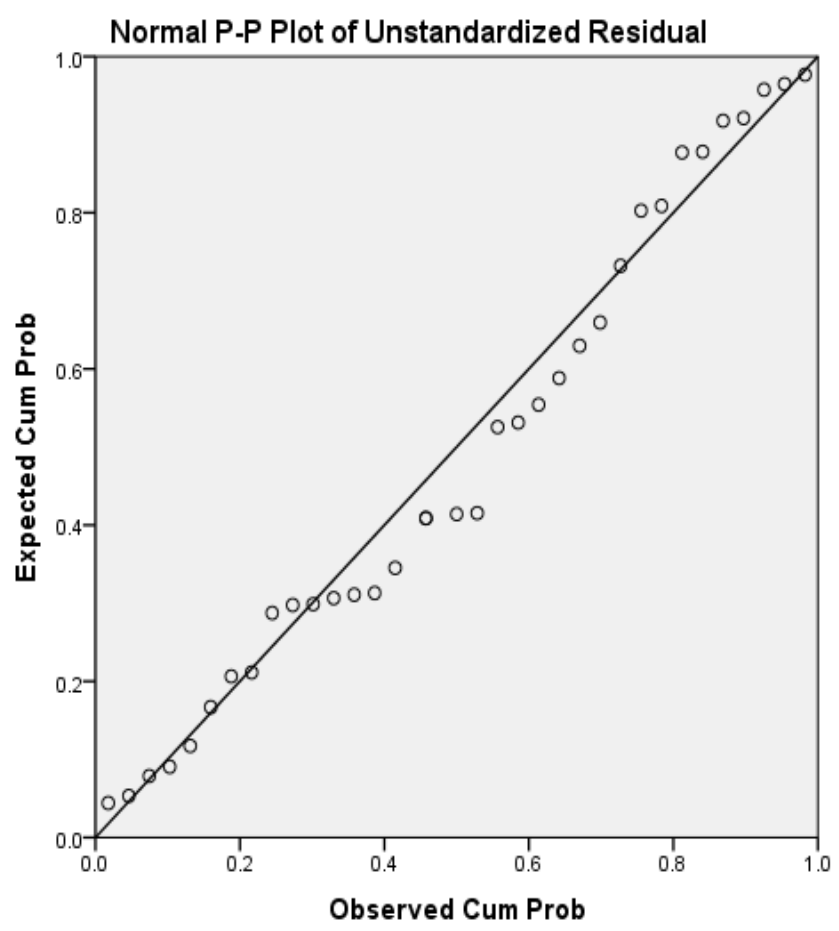

Gambar 2. Grafik P-P Plot

Tabel 5. menunjukan bahwa nilai signifikan untuk variabel motivasi sebesar $0,222(0,222>0,05)$, nilai signifikan untuk variabel kompensasi sebesar 0,123 $(0,123>0,05)$, dan nilai signifikan untuk variabel disiplin kerja sebesar 0,656 
$(0,656>0,05)$. Semua variabel bebas memiliki nilai signifikansi $>0,05$, maka tidak terjadi heteroskedastisitas pada model regresi. Hasil uji heteroskedastisitas juga dapat dilihat dari grafik scatterplots seperti Gambar 3.

\section{Tabel 5.}

Hasil Uji Heterokedastisitas

\begin{tabular}{|c|c|c|c|c|c|c|}
\hline \multicolumn{7}{|c|}{ Coefficients ${ }^{\mathrm{a}}$} \\
\hline \multirow{2}{*}{\multicolumn{2}{|c|}{ Model }} & Uns & ndardized & Standardized & $\mathbf{t}$ & Sig. \\
\hline & & B & Std. Error & Beta & & \\
\hline \multirow[t]{4}{*}{1} & (Constant) & .686 & .761 & & .901 & .375 \\
\hline & Motivasi & .075 & .060 & .316 & 1.245 & .222 \\
\hline & Kompensasi & -.088 & .056 & -.444 & -1.583 & .123 \\
\hline & Disiplin Kerja & .015 & .032 & .093 & .450 & .656 \\
\hline
\end{tabular}

Sumber: Data diolah, 2019

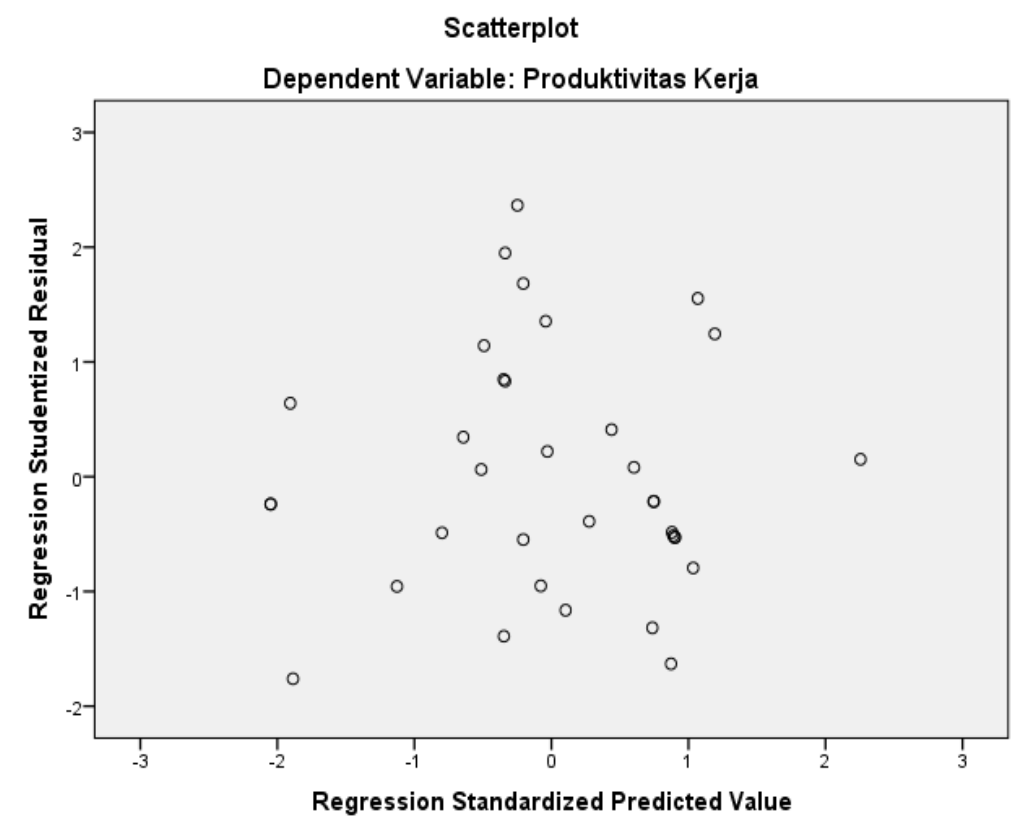

Gambar 3. Grafik Scatterplot

Berdasarkan Gambar 3. dapat dilihat bahwa tidak ada pola yang jelas, serta titik-titik menyebar di atas dan di bawah angka 0 pada sumbu Y, maka tidak terjadi heteroskedastisitas.

Uji multikolinearitas bertujuan untuk menemukan apakah ada kolerasi antara variabel bebas di dalam model regresi. Regresi yang baik seharusnya tidak terjadi kolerasi diantara variabel bebas. Untuk itu dilakukan uji multikolinearitas dengan melihat nilai tolerance dan variance inflation factor (VIF). Bila nilai tolerance lebih 
tinggi dari 0,1 atau nilai VIF kurang dari 10 , hal itu menunjukkan tidak adanya multikolinearitas.

Berdasarkan hasil uji pada Tabel 6. dapat diketahui bahwa nilai tolerance untuk variabel Motivasi sebesar 0,464 $(0,464>0,1)$ dengan nilai VIF sebesar 2,156 $(2,156<10)$, nilai tolerance untuk variabel Kompensasi sebesar 0,379 $(0,379>0,1)$ dengan nilai VIF sebesar 2,641 $(2,641<10)$, dan nilai tolerance untuk variabel Disiplin kerja sebesar 0,698 $(0,698>0,1)$ dengan nilai VIF sebesar 1,432 $(1,432<$ 10). Semua variabel pada model regresi berganda tersebut memiliki nilai tolerance lebih besar dari 0,1 dan nilai VIF lebih kecil dari 10 maka dapat disimpulkan bahwa model regresi yang digunakan bebas multikolinieritas.

Tabel 6.

Hasil Uji Multikolinieritas

\begin{tabular}{|c|c|c|c|}
\hline \multicolumn{4}{|c|}{ Coefficients ${ }^{\mathrm{a}}$} \\
\hline \multirow{2}{*}{\multicolumn{2}{|c|}{ Model }} & \multicolumn{2}{|c|}{ Collinearity Statistics } \\
\hline & & Tolerance & VIF \\
\hline \multirow[t]{3}{*}{1} & Motivasi & .464 & 2.156 \\
\hline & Kompensasi & .379 & 2.641 \\
\hline & Disiplin Kerja & .698 & 1.432 \\
\hline
\end{tabular}

Sumber: Data diolah, 2019

Berdasarkan hasil analisis data didapat bahwa Motivasi berpengaruh positif terhadap Produktivitas kerja. Hal tersebut ditunjukan dengan nilai signifikansi sebesar 0,027 dengan nilai koefisien regresi sebesar 0,256 bernilai positif. Nilai signifikansi $0,027<0,05$ mengindikasikan bahwa $\mathrm{H}_{1}$ diterima. Hasil ini mempunyai arti bahwa Motivasi diduga secara signifikan berhubungan dengan Produktivitas kerja. Hal ini berarti jika Motivasi semakin baik, maka Produktivitas kerja semakin baik, sebaliknya jika Motivasi semakin buruk maka Produktivitas kerja akan semakin buruk pula.

Perusahaan harus terus memotivasi para karyawannya, karena hal tersebut dapat mendorong karyawan-karyawannya untuk bekerja lebih baik lagi seperti yang dikatakan oleh Jayarathna (2014) dalam penelitiannya, motivasi berpengaruh terhadap produktivitas kerja para karyawan. Dalam penelitian yang dilakukan oleh Chaudary \& Sharma (2018), mengemukakan bahwa motivasi sangat berpengaruh terhadap produktivitas karyawan dan memperloeh hasil yang positif dan signifikan. Selain itu, Maduka dan Okafor (2014) dalam penelitiannya, memperoleh hasil yang sama bahwa motivasi berpengaruh positif dan signifikan terhadap produktivitas kerja.

Penelitian lain yang dilakukan oleh Nuraini et al. (2015) menyatakan bahwa, motivasi berpengaruh secara parsial terhadap produktivitas kerja karyawan. Purwanto \& Wulandari (2016) mendapatkan hasil dari penelitiannya yaitu, motivasi berpengaruh secara positif dan signifikan terhadap produktivitas kerja. Pengaruh yang positif tersebut menunjukan bahwa semakin baik persepsi responden mengenai dorongan motivasi kerja karyawan telah berhasil meningkatkan produktivitas kerja. Dengan demikian, semakin baik motivasi yang diberikan pada karyawan maka produktivitas kerja karyawan semakin baik juga. 
Berdasarkan hasil analisis data didapat bahwa Kompensasi berpengaruh positif terhadap Produktivitas kerja. Hal tersebut ditunjukan dengan nilai signifikansi sebesar 0,008 dengan nilai koefisien regresi sebesar 0,291 bernilai positif. Nilai signifikansi $0,008<0,05$ mengindikasikan bahwa $\mathrm{H}_{1}$ diterima. Hasil ini mempunyai arti bahwa Kompensasi diduga secara signifikan berhubungan dengan Produktivitas kerja. Hal ini berarti jika Kompensasi semakin baik, maka Produktivitas kerja semakin baik, sebaliknya jika Kompensasi semakin buruk maka Produktivitas kerja akan semakin buruk pula.

Kompensasi merupakan suatu imbalan yang diberikan atas jasa-jasa yang telah karyawan berikan dalam menyelesaikan suatu pekerjaan yang diberikan oleh perusahaan. Dengan pemberian kompensasi, semata-mata untuk membangun kinerja karyawan dan meningkatkan produktivitas kerja. Penelitian sebelumnya, yang dilakukan oleh Abdussamad (2014), mendapatkan hasil bahwa kompensasi berpengaruh signifikan terhadap produktivitas kerja. Perawati et al. (2018) dalam penelitiannya, menemukan bahwa terdapat pengaruh yang signifikan antara kompensasi dan produktivitas kerja.

Peneliti lain yaitu Yuliandari et al. (2014) memperoleh hasil bahwa kompensasi berpengaruh positif dan signifikan terhadap produktivitas kerja karyawan pada UD. Yuri Desa Pangkung Buluh Kecamatan Melaya Kabupaten Jembrana. Kompensasi berpengaruh secara langsung terhadap produktivitas kerja karyawan (Yamoah, 2013). Peneliti lain, Purwanto \& Wulandari (2016) mengatakan bahwa kompensasi mempunyai pengaruh positif dan signifikan terhadap produktivitas kerja karyawan. Dengan demikian, semakin baik kompensasi yang diberikan pada karyawan maka produktivitas kerja karyawan semakin baik juga.

Berdasarkan hasil analisis data didapat bahwa Disiplin kerja berpengaruh positif terhadap Produktivitas kerja. Hal tersebut ditunjukan dengan nilai signifikansi sebesar 0,000 dengan nilai koefisien regresi sebesar 0,275 bernilai positif. Nilai signifikansi $0,014<0,05$ mengindikasikan bahwa $\mathrm{H}_{1}$ diterima. Hasil ini mempunyai arti bahwa Disiplin kerja diduga secara signifikan berhubungan dengan Produktivitas kerja. Hal ini berarti jika Disiplin kerja semakin baik, maka Produktivitas kerja semakin baik, sebaliknya jika Disiplin kerja semakin buruk maka Produktivitas kerja akan semakin buruk pula.

Labudo (2013), menyatakan bahwa peningkatan produktivitas dapat dicapai jika karyawan mempunyai disiplin kerja dalam melaksanakan tugas dan kewajibannya. Ruauw et al. (2015) dalam penelitiannya, mendapatkan hasil bahwa disiplin kerja pegawai berpengaruh signifikan terhadap produktivitas kerja pegawai. Wardoyo (2015) dalam penelitiannya menemukan hasil bahwa terdapat pengaruh yang signifikan antara disiplin kerja dengan produktivitas kerja.

Christian \& Farida (2016) dalam penelitiannya menemukan bahwa pengaruh disiplin kerja terhadap produktivitas kerja karyawan yaitu berpengaruh signifikan. Peneliti lain, Ananta \& Adnyani (2016) mengatakan bahwa disiplin kerja berpengaruh positif dan signifikan terhadap produktivitas kerja karyawan.

Hasil penelitian ini memiliki implikasi secara teoritis, yang dimana penelitian ini menunjukan motivasi, kompensasi dan disiplin kerja berpengaruh positif dan signifikan terhadap produktivitas kerja. Hasil penelitian ini memberikan dukungan 
empiris dan dapat memperkuat penelitian-penelitian sebelumnya. Selain itu, hasil penelitian ini juga memiliki implikasi secara praktis, yaitu penelitian ini diharapkan dapat memberikan manfaat bagi pimimpinan dan karyawan dari PT. Lila Buana Wisata yang dimana perusahaan harus melakukan pendekatan memotivasi karyawan secara terus menerus agar semangat kerja karyawan meningkat sehingga produktivitas kerjanya juga meningkat. Selain itu, perusahaan juga perlu memberikan kompensasi yang sesuai dengan pekerjaan karyawan yang nantinya akan berpengaruh terhadap produktivitas kerja karyawan. Pihak perusahaan juga perlu memperhatikan kedisiplinan karyawan yang harapannya produktivitas kerja karyawan tersebut meningkat.

\section{SIMPULAN}

Motivasi berpengaruh positif dan signifikan terhadap produktivitas kerja. Hal ini berarti semakin tinggi motivasi maka produktivitas kerja karyawan akan semakin meningkat. Demikian sebaliknya, semakin rendah motivasi maka produktivitas kerja akan semakin menurun. Kompensasi berpengaruh positif dan signifikan terhadap Produktivitas kerja. Hal ini berarti semakin baik kompensasi yang diberikan maka produktivitas kerja akan semakin meningkat. Demikian sebaliknya, jika semakin buruk kompensasi yang diberikan maka produktivitas kerja akan semakin menurun. Disiplin kerja berpengaruh positif dan signifikan terhadap Produktivitas kerja. Hal ini berarti semakin tinggi disiplin kerja maka produktivitas kerja karyawan akan semakin meningkat. Demikian sebaliknya, semakin rendah disiplin kerja maka produktivitas kerja akan semakin menurun.

Untuk mengatasi permasalahan karyawan yang belum mampu bekerja dalam keadaan lingkungan yang kurang mendukung, maka perusahaan perlu meningkatkan lagi lingkungan kerja dan lebih memotivasi karyawannya dengan memberi semangat dan reward untuk karyawan yang sudah melakukan tugasnya dengan baik. Perusahaan harus lebih memperhatikan mengenai kompensasi yang diberikan untuk karyawannya. Untuk mengatasi permasalahan kompensasi yang dimana karyawan tidak menerima gaji sesuai dengan hak atas pekerjaannya, maka pimpinan PT. Lila Buana Wisata perlu bersikap adil terhadap hak karyawannya. Karyawan yang menerima baik kompensasi mereka, dapat mendorong karyawan untuk bersedia bekerja lebih produktif untuk kemajuan perusahaan. Untuk mengatasi permasalahan disiplin kerja yang dimana karyawan tidak mematuhi aturan jam kerja yang sudah ditentukan oleh perusahaan dan kurang bertanggung jawab, maka perusahaan perlu memberi teguran yang sesuai aturan perusahaan sehingga karyawan bisa lebih disiplin lagi.

\section{REFERENSI}

Abdussamad, Z. (2014). Pengaruh Kompensasi Terhadap Produktivitas Kerja Karyawanpada Pt Asuransi Jiwasraya Gorontalo. Jurnal Manajemen, 18(3), $456-466$.

Agustina, H. (2016). Pengaruh Kompensasi Dan Beban Kerja Terhadap Loyalitas Karyawan Di Departemen Operasi Pt. Pupuk Sriwidjaja Palembang. Jurnal 
Ecoment Global, 1(2), 56. https://doi.org/10.35908/jeg.v1i2.204

Almingo, N. (2018). Hubungan Antara Kepuasan Kerja dengan Produktivitas Kerja Karyawan. Jurnal PSYCHE, 1(1), 50-60.

Ananta, I. K. F., \& Adnyani, I. G. A. D. (2016). Pengaruh Disiplin Kerja Dan Budaya Orgasnisasi Terhadap Produktivitas Kerja Karyawan Pada Villa Mahapala Sanur-Denpasar. E-Jurnal Manajemen Universitas Udayana, 5(2), 1103-1130.

Aprilliansyah, A., Astuti, E. S., \& Sulityo, M. C. W. (2018). Analisis Kompensasi dan Servant Leadership Pengaruhnya terhadap Motivasi Kerja dan Kinerja Karyawan ( Studi pada Leader Nasional unit bisnis Multilevel marketing PT Melia Sehat Sejahtera Kota Surabaya Cabang Jawa Timur ). Jurnal Administrasi Bisnis, 61(3), 73-82.

Bintang, D. H. (2016). JOM FISIP Vol. 3 No. 2 - Oktober 2016 Page 1. JOM FISIP, 3(2), 1-15.

Chaudary, N., \& Sharma, D. B. (2018). Impact of Employee Motivation on Work Performance. International Journal of Scientific and Research Publications (IJSRP), 8(3), 29-35. https://doi.org/10.29322/ijsrp.8.3.2018.p7544

Christian, F. A., \& Farida, L. (2016). Pengaruh Disiplin Kerja terhadap Produktivitas Kerja Karyawan Bagian Produksi Pabrik Kelapa Sawit (PKS) PT. Perkebunan Nusantara V SEI Rokan Kec. Pagaran Tapah Darussalam Kab. Rokan Hulu. JOM FISIP, 3(1), 1-15.

Elqadri, Z. M., Wardoyo, D. T. W., \& Priyono. (2015). The Influence of Motivation and Discipline Work against Employee Work Productivity Tona'an Markets. Review of European Studies, 7(12), 58-66. https://doi.org/10.5539/res.v7n12p59

Fauzi, I., \& Widjana, A. (2018). Pengaruh Kompensasi dan Program (K3) Keselamatan Kesehatan Kerja terhadap Produktivitas Karyawan pada Bagian Pengolahan di PT. Perkebunan Nusantara VIII Gedeh Cianjur. Elib Unikom, 1-12.

Ghazanfar, F., Chuanmin, S., Khan, M. M., \& Bashir, M. (2011). A Study of Relation between Satisfaction with Compensation and Work Motivation. International Journal of Business and Social Science, 2(1), 120-131.

Hafid, H. (2018). Pengaruh Kompetensi, Kepemimpinan Dan Disiplin Kerja Terhadap Kinerja Pegawai Pada Samsat Polewali Mandar. Development Research of Management: Jurnal Manajemen, 13(2), 286-310.

Hanaysha, J. (2016). Improving employee productivity through work engagement: Evidence from higher education sector. Management Science Letters, 6, 6170. https://doi.org/10.5267/j.msl.2015.11.006 
Harliawan, H., Yasa, I. G. W. M., \& Dewi, M. H. U. (2017). Pengaruh Kompensasi, Pendidikan dan Program Kesejahteraan terhadap Produktivitas Kerja Wartawan di Provinsi Bali. E-Jurnal Ekonomi Dan Bisnis Universitas Udayana, 7(6), 2697-2730.

Jayarathna, S. M. D. Y. (2014). An Empirical Investigation of the Impact of Employee Motivation and Productivity of Executive Employees with Special Reference to the Apparel Industry in Sri Lanka. International Journal of Science and Research, 3(3), 749-754.

Kasmawati. (2018). Sumber Daya Manusia Sebagai Sumber Keunggulan Kompetitif. Idaarah: Jurnal Manajemen Pendidikan, 2(2), 229. https://doi.org/10.24252/idaarah.v2i2.6864

Kusuma, Y. B., Swasto, S., \& Musadieq, M. Al. (2015). Pengaruh Kompensasi terhadap Motivasi Kerja, Kepuasan Kerja dan Kinerja Karyawan (Studi pada Karyawan Tetap PT . Otsuka Indonesia di Lawang, Malang). EJournal Fakultas Ilmu Administrasi Universitas Brawijaya, 9(1), 43-56.

Labudo, Y. (2013). Disiplin Kerja Dan Kompensasi Pengaruhnya Terhadap Produktivitas Karyawan. Jurnal Riset Ekonomi, Manajemen, Bisnis Dan Akuntansi, 1(3), 55-62.

Lusri, L., \& Siagian, H. (2017). Pengaruh Motivasi Kerja Terhadap Kinerja Karyawan Melalui Kepuasan Kerja Sebagai Variabel Mediasi Pada Karyawan Pt . Borwita Citra Prima Surabaya. Agora, 5(1), 2-8.

Maduka, C. E., \& Okafor, O. (2014). Effect of Motivation on Employee Productivity: A Study of Manufacturing Companies in Nnewi. International Journal of Managerial Studies and Research, 2(7), 137-147. www.arcjournals.org

Muammam, M., Pramono, R. E., \& Supriyanto, T. (2013). Hubungan Motivasi Kerja Dengan Produktivitas Kerja Karyawan PT. Yamaha Bintang Motor di Situbondo. Artikel Ilmiah Hasil Penelitian Mahasiswa, 2(7), 1-6.

Mulyadi, H. (2010). Pengaruh Motivasi dan Kompetensi Kerja Terhadap Produktivitas Kerja Karyawan pada PT Galamedia Bandung Perkasa. Manajerial : Jurnal Manajemen Dan Sistem Informasi, 9(2), 97-111. http://ejournal.upi.edu/index.php/manajerial/article/view/1807/1238

Nuraini, Indarti, S., \& Marzolina. (2015). Pengaruh lingkungan kerja dan motivasi terhadap produktivitas kerja karyawan pada PT. Perkebunan Nusantara V Cabang Kebun Inti kecamatan Tapung Kabupaten Kampar. Jom FEKON, 2(1), 1-15.

Perawati, Lian, B., \& Tobari. (2018). The Influence of Compensation, Work Motivation and Discipline on Teacher's Work Productivity. European Journal of Education Studies, 5(7), 202-213. 
https://doi.org/10.5281/zenodo.2371953

Permatasari, J., Musadieq, M. Al, \& Mayoan, Y. (2015). Pengaruh Disiplin Kerja dan Motivasi Kerja terhadap Prestasi Kerja Karyawan (Studi pada PT BPR Gunung Ringgit Malang). Jurnal Administrasi Bisnis, 25(1), 1-9.

Prabawa, I. M. A., \& Supartha, I. W. G. (2017). Meningkatkan Produktivitas Karyawan Melalui Pemberdayaan, Kerja Sama Tim dan Pelatihan di Perusahaan Jasa. E-Jurnal Manajemen Universitas Udayana, 7(1), 497. https://doi.org/10.24843/ejmunud.2018.v7.i01.p19

Purwanto, A. B., \& Wulandari, O. (2016). Pengaruh Motivasi, Kompensasi dan Lingkungan Kerja Terhadap Produktivitas Kerja Karyawan. Buletin Bisnis \& Manajemen, 2(1), 9-26. http://journal.stieyppi.ac.id/index.php/BBM/article/view/2/2

Rivai, V. (2011). Manajemen Sumber Daya Manusia untuk Perusahaan Teori ke Praktek. Raja Grafindo Persada.

Ruauw, A., Lengkong, F., \& Mandey, J. (2015). Pengaruh Disiplin Kerja Terhadap Produktivitas Pegawai (suatu studi di Kantor Kelurahan Tingkulu Kecamatan Wanea Kota Manado). Jurnal Administrasi Publik, 3(31), 1-10.

Samsuni. (2017). Manajemen Sumber Daya Manusia. Al Falah, 17(31), 113-124. http://ejurnal.staialfalahbjb.ac.id/index.php/alfalahjikk/article/view/19

Sibarani, E. (2013). Pengaruh Motivasi dan Disiplin Kerja terhadap Kinerja Perawat pada Rumah Sakit Swasta Lancang Kuning Pekan Baru. Journal of Petrology, 369(1), 1689-1699.

https://doi.org/10.1017/CBO9781107415324.004

Wardoyo, D. T. W. (2015). The Influence of the Discipline and Compensation against Work Productivity (Study on the Security Services Company, PT Garuda Milky Artha Surabaya). International Journal of Business and Management, 11(1), 64. https://doi.org/10.5539/ijbm.v11n1p64

Yamoah, E. E. (2013). Relationship between Compensation and Employee Productivity. Singaporean Journal of Business , Economics and Management Studies, 2(1), 110-114. https://doi.org/10.12816/0003845

Yuliandari, N. K., Bagia, I. W., \& Suwendra, I. W. (2014). Pengaruh Kompensasi dan Lingkungan Kerja Terhadap Produktivitas Kerja Karyawan Bagian Loster Pada UD Yuri Desa Pangkung Buluh Kecamatan Melaya Kabupaten Jembrana. E-Journal Bisma, 2(3).

Zainal, H. (2017). Influence of Work Motivation and Discipline on Work Productivity. Advances in Social Science, Education and Humanities Research (ASSEHR), 149, 25-27. https://doi.org/10.2991/icest-17.2017.9 
Made Dani Suryadewi, Pengaruh Motivasi, Kompensasi...

Zameer, H., Ali, S., Nisar, W., \& Amir, M. (2014). The Impact of the Motivation on the Employee's Performance in Beverage Industry of Pakistan.

International Journal of Academic Research in Accounting, Finance and Management Sciences, 4(1), 293-298. https://doi.org/10.6007/ijarafms/v4i1/630 